PERM JOURNAL OF PETROLEUM AND MINING ENGINEERING ВЕСТНИК ПНИПУ. ГЕОЛОГИЯ. НЕФТЕГАЗОВОЕ И ГОРНОЕ ДЕЛО ISSN 2224-9923 Volume/ Toм 19 №2 2019

$\mathrm{http}: / /$ vestnik,pstu.ru/geo/

UDC 622.276+551.782.2:622.831

Article / Статья

(c) PNRPU / ПНИПУ, 2019

\title{
INFUENCE OF GEODYNAMICAL REGIME ON FORMATION OF GEOLOGICAL STRUCTURE AND PETROPHYSICAL CHARACTERISTICS OF PLIOCENE SEDIMENTS IN KHAMAMDAG-DENIZ FIELD IN BAKU ARCHIPELAGO
}

\section{Vagif Sh. Gurbanov, Adalat B. Hasanov ${ }^{1}$, Latif A. Sultanov ${ }^{1}$, Mais S. Babaev ${ }^{1}$ \\ Oil and Gas Institute of the Azerbaijan National Academy of Science (9 F. Amirov st., Baku, AZ 1001, Republic of Azerbaijan) \\ ${ }^{1}$ Azerbaijan State Oil and Industry University (20 Azadlyg av., Baku, AZ1010, Republic of Azerbaijan) \\ ВЛИЯНИЕ ГЕОДИНАМИЧЕСКОГО РЕЖИМА НА ФОРМИРОВАНИЕ ГЕОЛОГИЧЕСКОГО СТРОЕНИЯ И ПЕТРОФИЗИЧЕСКИЕ ХАРАКТЕРИСТИКИ ПЛИОЦЕНОВЫХ ОТЛОЖЕНИЙ МЕСТОРОЖДЕНИЯ ХАМАМДАГ-ДЕНИЗ БАКИНСКОГО АРХИПЕЛАГА}

\section{В.Ш. Гурбанов, А.Б. Гасанов ${ }^{1}$, Л.А. Султанов ${ }^{1}$, М.С. Бабаев ${ }^{1}$}

Национальная академия наук Азербайджана. Институт нефти и газа (AZ1001, Азербайджан, г. Баку, ул. Ф. Амирова, 9) ${ }^{1}$ Азербайджанский государственный университет нефти и промышленности (AZ1010, Азербайджан, г. Баку, пр. Азадлыг, 20) Received / Получена: 18.01.2019. Accepted / Принята: 01.06.2019. Published / Опубликована: 28.06.2019

Key words: geodynamical regime, petrophysical characteristics, pliocene sediments, granulometric composition of rocks, pertophysics, density, porosity, Meso-Cenozoic, oil and gas accumulation, rocks, lithofacies, graph-analytic, reservoir, carbonateness, longitudinal wave velocity, terrigenous-carbonate sediments.
Ключевые слова: геодинамический режим, петрофизические характеристики, плиоценовые отложения, гранулометрический состав пород, петрофизика, плотность, пористость, мезокайнозой, нефтегазонакопления, породы, литофации, графоаналитический, коллектор, карбонатность, скорость продольных волн, терригеннокарбонатные отложения.
This article presents complex results of petrophysical studies of rock samples from exploratory wells in area of Khamamdag-Deniz field, where sediments of pliocene time are widely spread. Selection of object of the study is related to the fact that in the given deposit within range of pliocene rocks depth degradation of porosity and permeability is different from traditionally forecasted, and at rather big depths primary reservoir productivity may be preserved, or acquired reservoir productivity may appear. Studies have shown that physical characteristics of rocks of the same age and same name may differ during lithogenesis process and due to influence of geological and geophysical factors. Reservoir properties of sedimentary rocks of pliocene age were studied. Data collected within the study are summarized in a table showing variation of physical properties of different reservoir rocks and regularity of their alteration by area and depth of showing variation of physical properties of different reservoir rocks and regularity of their alteration by area and depth of
location, with regard to geological peculiarities of the section. Except that, average values of granulometric composition of
rocks by depth along the whole section of the abovementioned area were analyzed. It is found that at shallow depths (835rocks by depth along the whole section of the abovementioned area were analyzed. It is found that at shallow depths (835-
$1088 \mathrm{~m}$ ) rock fractional composition is favorable to high porosity (maximum 26,6\%) and is accompanied by high speed of ultrasound waves propagation $(3000 \mathrm{~m} / \mathrm{sec})$ and density $\left(2,28 \mathrm{~g} / \mathrm{cm}^{3}\right)$. At medium depths $(3669 \mathrm{~m})$ with predominance of aleurolites $\left(69,6 \%\right.$ ) maximal rock porosity is, $0 \%$, and permeability $32,6 \cdot 10^{-15} \mathrm{~m}^{2}$, which may be related to good grain grading degree and their weak compactness (as demonstrated by relatively low density and speed of ultrasound waves).
Further, at large depths $(4439 \mathrm{~m})$ sandy-argillaceous aleurolites occurs, with contents of $53,3 \%$ aleurolites, $21,9 \%$ sand, Further, at large depths (4439 m) sandy-argillaceous aleurolites occurs, with contents of $53,3 \%$ aleurolites, $21,9 \%$ sand,
$36,1 \%$ clays and carbonate content $19,9 \%$. Here rock porosity is significantly less (maximum $21,3 \%$ ) and also rock permeability $129,0 \cdot 10^{-15} \mathrm{~m}^{2}$, showing relatively low degree of grading and related to it higher compactness of these sediments. This is also demonstrated by high speed of ultrasound waves propagation within the range of studied depths. Except that, the article reviews issues of permeability dependency on porosity, and porosity dependence on depth.

Изложены комплексные результаты петрофизических исследований образцов пород, отобранные из поисково-разведочных скважин по площади месторождения Хамамдаг-Дениз, где широко распространены отложения плиоценовой толщи. Выбор объекта исследований связан с тем, что на указанном месторождении в интервале залегания плиоценовых толщ глубинное ухудшение пористости и проницаемости отклоняется от традиционно прогнозируемого, и на довольно больших глубинах может сохраняться первичная либо возникать приобретенная продуктивность коллекторов. Исследования показали, что физические характеристики одновозрастных и одноименных пород могут отличаться в процессе литогенеза и вследствие влияния геологогеофизических факторов. Были изучены коллекторские свойства осадочных пород плиоценового возраста. Полученные данные геофизических факторов. Были изучены коллекторские свойства осадочных пород плиоценового возраста. Полученные данные сведены в таблицу, отражающую вариацию физических свойств различных типов пород-коллекторов и закономерность их средние значения гранулометрического состава пород по глубине вдоль всего разреза вышеуказанной площади. Выявлено, что на малых глубинах $(835-1088$ м) фракционный состав пород благоприятствует высокой пористости (максимум 26,6 \%) и сопровождается высокой скоростью распространения ультразвуковых волн $(3000$ м/с) и плотностью $(2,28$ г/см³). На средних глубинах (3669 м) при доминировании алевролитов (69,6 \%) максимальная пористость пород составляет 20,0 \%, а проницаемость $32,6 \cdot 10^{-15} \mathrm{M}^{2}$, что может быть связано с хорошей отсортированностью зерен и слабой их уплотненностью (на это указывают относительно низкая плотность и скорость ультразвуковьх волн). Далее, на больших глубинах (4439 м) залегают песчаноглноситльно низкая плотность и скорость ультразвуковых волн). Далее, на больших глубинах (4439 м) залегают песчаноглинистые алевролиты с содержанием 53,3 \% алевритов, $21,9 \%$ песков, 36,1 \% глин и карбонатностью $19,9 \%$. Здесь существенно
ниже пористость (максимум 21,3\%) и проницаемость $129,0 \cdot 10^{-15} \mathrm{~m}^{2}$ пород, что свидетельствует об относительно низкой отсортированности и связанной с ней более высокой плотности этих отложений. На это также указывает высокая скорость распространения ультразвуковых волн в пределах рассматриваемых глубин. Кроме того, в статье пересмотрены вопрось зависимости проницаемости от пористости, а пористости от глубины.

Vagif Sh. Gurbanov (Author ID in Scopus: 26028826000, 57193747031) - Doctor of Geology and Mineralogy, Professor, Deputy Director for Science (mob. tel.: +994502 140 969, e-mail: vagifqurbanov@mail.ru). The contact person for correspondence.

Adalat B. Hasanov (Author ID in Scopus: 57204726953) - Doctor of Physics and Mathematics, Director of the Laboratory "Physical characteristics of rocks of mineral fields" (mob. tel.: +994 502231 255, e-mail: adalathasanov@yahoo.com).

Latif A. Sultanov (Author ID in Scopus: 57209321385 ) - Researcher of the Laboratory "Physical characteristics of rocks of mineral fields" (mob. tel.: +994 503 279 701 , e-mail: latif.sultan@mail.ru).

Mais S. Babayev - PhD in Geology and Mineralogy, Associate Professor, Head of the Department of Oil and Gas Geology (mob. tel.: +994 505 956 237, e-mail: m.s.babayev@mail.ru).

Гурбанов Вагиф Шыхы оглы - доктор геолого-минералогических наук, профессор, заместитель директора по научном вопросам Института нефти и газа (тел.: +9945021409 69, e-mail: vagifqurbanov@mail.ru). Контактное лицо для переписки.

Гасанов Адалат Бадал оглы - доктор физико-математических наук, заведующий лабораторией физических свойств горных пород месторождений полезных ископаемых (тел.: +994 5022312 55, e-mail: adalathasanov@yahoo.com)

Султанов Латиф Агамирза оглы - научный сотрудник лаборатории физических свойств горных пород месторождений полезных ископаемых Султанов Латиф Агамирза оглы - научный

Бабаев Маис Саркар оглы - кандидат геолого-минералогических наук, доцент, заведующий кафедрой геологии нефти и газа (тел.:+994 505956237 , e-mail: m.s.babayev@mail.ru). 


\section{Introduction}

Study of reservoir properties of rocks is one of the most important tasks in determining prospectivity of oil and gas containing formations and reserve calculation at explored fields. Except that, modern stage of development of oil and gas industry demands to increase effectiveness and improvement of technological processes of development of oil and gas deposits.

One of prospective structures in Baku archipelago - Khamamdag-Deniz (fig. 1) - was found in first half of previous century by map drilling, and then studied in more details by core and deep hole exploratory drilling.

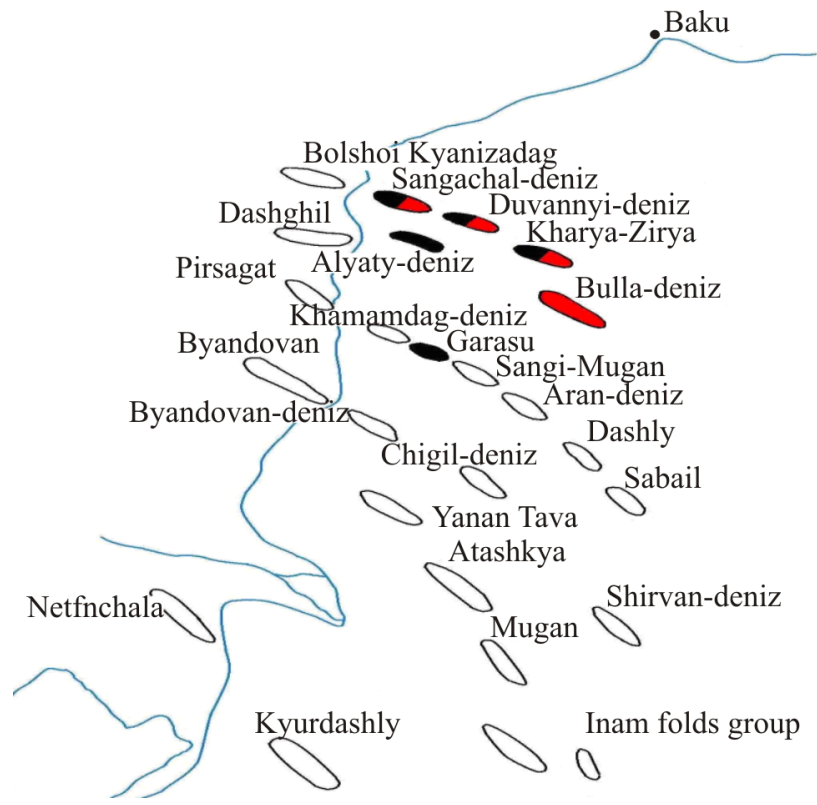

Fig. 1. Location of Khamamdag-Deniz in structural plan of Baku archipelago

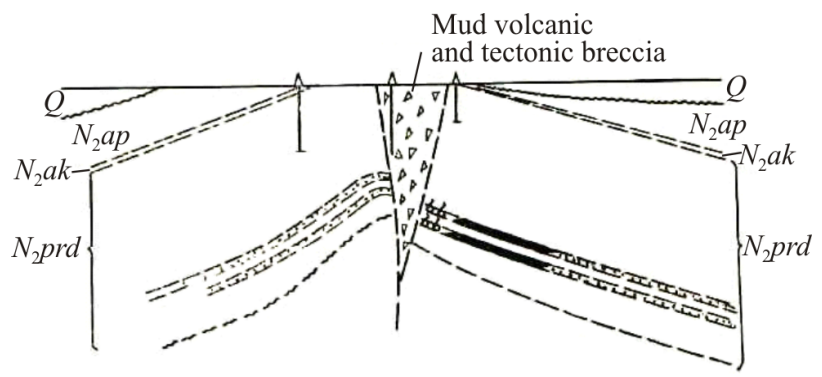

Fig. 2. Geological section of Khamamdag-Deniz structure

Taking into account that in the archipelago there are structures not fully studied, and also possibility to discover new oil and gas deposits, we have analyzed petrophysical characteristics of core samples taken from exploratory wells drilled in Khamamdag-Deniz field and adjacent areas. Analytic and graphical generalizations were performed for average values and variation ranges of data of granulometric analysis and reservoir properties of pliocene age sediments. It is established that in result of geological processes petrophysical properties of rocks of same type and same age underwent alterations within wide range of values.

Khamamdag-Deniz structure is geographically located to south-east of Pirsagat structure (see fig. 1). North-western periclinal part of the fold was mapped in 1936-1937. In 1950 map drilling was performed at sea from a launch. Its results confirmed presence of an independent uplift here. Seismic works were performed in 1951-1952. Later in 1954-1955 core drilling was performed in the area.

\section{Oil and gas content and lithological and petrohysical characteristics of Pliocene age sediments in Khamamdag-Deniz field in Baku archipelago}

In geological composition of Khamamdag-Deniz structure participate Akchagyl and Apsheron sediments, and also upper parts of productive strata. The latter sediments in crest area of the fold are eroded to depth of $900 \mathrm{~m}$ from the roof. The exposed part of the section is presented by gray, grayishbrown sandy clays with thin (from 0,05 to $1,5 \mathrm{~m}$ ) layers of gray clay sands.

Akchagyl stage is presented by gray, dark gray laminated clays with thin layers of sands and volcanic ashes with thickness 70-80 m. Also formational breccia is found in the section.

Apsheron stage is developed in limb and periclinal parts of the structure and is presented by all three substages. Shelly limestones of Apsheron stage in south-western limb of the structure in some places are above water and form small islands.

In general Apsheron stage, about $900 \mathrm{~m}$ thick, is formed by alternation of gray, dark gray clays, shelly limestones, sandstones. Content of limestones increase in middle and upper substages.

In tectonic aspect Khamamdag-Deniz area is a symmetrical brachyanticlinal fold trending to southwest of the stretch (fig. 2) with slope angles $25-40^{\circ}$ at both limbs. North-western periclinal part of the structure is located on shore, where mud volcano Khamamdag-Deniz is located.

As in the archipelago in whole, here prospective are sediments of VII horizon in lower part of productive strata. 
While drilling first two or three exploratory wells with purpose to enter Miocenic sediments they were drilled deeper to $5000 \mathrm{~m}[1-6]$.

Granulometric composition (\%), carbonateness $(\%)$, porosity $\left(K_{\mathrm{m}}, \%\right)$, permeability $\left(10^{-15} \mathrm{~m}^{2}\right)$, density $\left(\sigma, \mathrm{g} / \mathrm{cm}^{3}\right)$ and ultrasound waves propagation velocity $(V, \mathrm{~m} / \mathrm{sec})$ were studied in drilling.

As result of study of rocks granulometric composition in Pliocene age sediments over Khamamdag-Deniz area it was established that diameter of grains forming the sediments changes in range from over 0,25 to less than $0,1 \mathrm{~mm}$, which shows that aleurolites are predominant in the section (table 1). As is follows from table 1, granulometric composition of Pliocene age sediments changes: in sands - from 4,9 to $50,0 \%$, in aleurolites $-24,1-69,9$ $\%$, in clays - from 22,6 to $90,0 \%$. On basis of the given data we determined regularity of distribution of physical properties of different age rocks from lithostratigraphic units participating in geological composition of the area, and also range of variations of strata reservoir properties was established, with average values calculation. From generalized analysis of fractional composition in section of Pliocene strata it is possible to conclude that it is presented mainly by aleurolites, except for depth range 3780-3835 $\mathrm{m}$, where dominate psammites $(61,7 \%)$ and aleurites $(24,0 \%)$. That is, range 3780 $3835 \mathrm{~m}$ is presented by argillaceous-silt sandstones.

More detailed analysis of rock reservoir properties dependency on granulometric composition with regard of depth influence shows (fig. 3, $a-c$ ), that at shallow depths $(835-1088 \mathrm{~m})$ rocks fractional composition is favorable to high porosity (maximum $26,6 \%)$ and is accompanied by high velocity of ultrasound waves propagation $(3000 \mathrm{~m} / \mathrm{sec})$ and density $\left(2,28 \mathrm{~g} / \mathrm{cm}^{3}\right)$ (see table 1$)$.

At medium depths $(3669 \mathrm{~m})$ with dominance of aleurolites $(69,6 \%)$ maximal rock porosity is $20,0 \%$, and permeability $-32,6 \cdot 10^{-15} \mathrm{~m}^{2}$, which may be relayed to good grading of grains and their weak compactness (which is demonstrated by relatively low density and velocity of ultrasound waves).

Further, and deeper depths (4439 m) lay sandyargillaceous aleurolites with content of aleurolites $53,3 \%$, sands $21,9 \%$, clays $36,1 \%$ and carbonateness $19,9 \%$. Here substantially lower are porosity (maximum 21,3\%) and permeability $129,0 \cdot 10^{-15} \mathrm{~m}^{2}$ of rocks, which says of relatively low grading and related to it higher density of the sediments. This is also demonstrated by high ultrasound waves propagation velocity within these depths [7-27].

Table 1

Results of petrophysical studies of Pliocene age sediments at Khamamdag-Deniz field

\begin{tabular}{|c|c|c|c|c|c|c|c|c|}
\hline \multirow{2}{*}{$\begin{array}{c}\text { Depth } \\
\text { range, } m\end{array}$} & \multicolumn{3}{|c|}{ Granulometric composition, \% } & \multirow{2}{*}{$\begin{array}{c}\text { Carbonateness, } \\
\%\end{array}$} & \multirow[b]{2}{*}{ Porosity, \% } & \multirow{2}{*}{$\begin{array}{l}\text { Permeability, } \\
10^{-15} \mathrm{~m}^{2}\end{array}$} & \multirow{2}{*}{$\begin{array}{l}\text { Density } \sigma \\
\mathrm{g} / \mathrm{cm}^{3}\end{array}$} & \multirow{2}{*}{$\begin{array}{c}\text { Velocity of } \\
\text { ultrasound } \\
\text { propagation } V, \\
\mathrm{~m} / \mathrm{sec}\end{array}$} \\
\hline & $\begin{array}{c}\text { fraction over } \\
0,25-0,1\end{array}$ & $\begin{array}{c}\text { fraction } \\
0,1-0,01 \\
\end{array}$ & $\begin{array}{c}\text { fraction less } \\
0,01 \\
\end{array}$ & & & & & \\
\hline \multirow{2}{*}{$502-834$} & $0,3-49,95$ & $7,99-66,6$ & $26,32-90,89$ & $7,3-20,4$ & $2,0-24,4$ & $\operatorname{Im}$ & $2,0-2,36$ & $2430-2920$ \\
\hline & $9,62(39)$ & $\overline{42,39(39)}$ & $47,74(39)$ & $\overline{14,54(39)}$ & $\overline{15,25(20)}$ & $\mathrm{y}$ & $2,15(19)$ & $2675(5)$ \\
\hline \multirow{2}{*}{$835-1088$} & $1,2-56,1$ & $4,6-68,8$ & $30,0-46,8$ & $11,0-22,1$ & $9,0-26,6$ & $9,0-987,0$ & $1,91-2,41$ & $1900-3500$ \\
\hline & $\overline{16,01(10)}$ & $\overline{38,77(10)}$ & $40,32(10)$ & $\overline{15,19(44)}$ & $\overline{18,62(60)}$ & $101,8(20)$ & $2,28(60)$ & $3000(47)$ \\
\hline \multirow{2}{*}{$1100-1200$} & $9,3-14,0$ & $44,6-57,2$ & $28,7-46,0$ & $12,0-17,0$ & $12,7-24,5$ & $0,53-11,0$ & $2,17-2,31$ & $2800-3200$ \\
\hline & $\overline{11,65(2)}$ & $50,90(2)$ & $37,35(2)$ & $14,5(4)$ & $17,14(4)$ & $5,63(4)$ & $2,25(4)$ & $2950(4)$ \\
\hline \multirow{2}{*}{$1450-1800$} & $2,7-36,0$ & $24,6-57,4$ & $17,1-46,2$ & $7,5-22,0$ & $12,1-22,4$ & $5,0-26,0$ & $2,01-2,33$ & $2300-3500$ \\
\hline & $\overline{18,98(2)}$ & $43,22(3)$ & $37,64(3)$ & $\overline{13,39(4)}$ & $14,9(4)$ & $\overline{12,28(4)}$ & $2,26(4)$ & $2960(4)$ \\
\hline \multirow[b]{2}{*}{$2500-3669$} & $2,5-60,2$ & $22,2-69,6$ & $14,0-42,0$ & $9,9-17,9$ & $7,8-20,0$ & $1,24-32,6$ & \multirow[b]{2}{*}{2,24} & \multirow[b]{2}{*}{2550} \\
\hline & $\overline{29,38(4)}$ & $\overline{42,60(4)}$ & $\overline{26,70(4)}$ & $\overline{13,40(4)}$ & $11,63(4)$ & $20,51(4)$ & & \\
\hline \multirow{2}{*}{$3780-3835$} & $1,0-34,1$ & $9,6-37,9$ & $27,8-86,8$ & $3,3-17,3$ & $11,1-14,5$ & $0-154$ & \multirow{2}{*}{2,23} & \multirow{2}{*}{2750} \\
\hline & $\overline{16,50(3)}$ & $24,13(3)$ & $58,55(3)$ & $9,38(3)$ & $13,33(3)$ & $\overline{74,0(3)}$ & & \\
\hline $4025-4114$ & 33,0 & 43,7 & 22,6 & 32,3 & 8,1 & 0,11 & 26 & 2800 \\
\hline \multirow{2}{*}{ 4114-4439 } & $10,5-44,5$ & $24,1-53,3$ & $29,5-48,8$ & $8,9-15,9$ & $10,7-21,3$ & $0,23-129,0$ & \multirow{2}{*}{2,24} & \multirow{2}{*}{2700} \\
\hline & $21,20(5)$ & $41,25(5)$ & $36,38(5)$ & $\overline{12,65(5)}$ & $14,38(5)$ & $33,75(5)$ & & \\
\hline
\end{tabular}

Note: in the numerator - extreme values, in the denominator - average values of the parameters, in brackets - number of samples studied. 


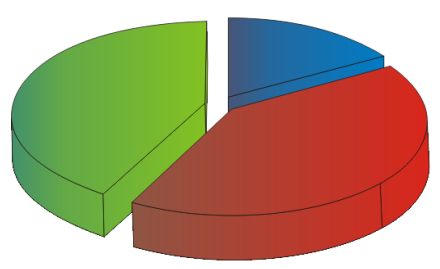

$a$

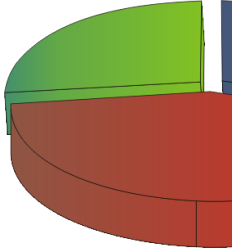

$b$

$0,25-0,10$

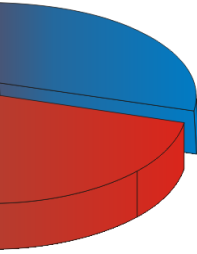

(1)

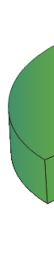

$0,10-0,01$

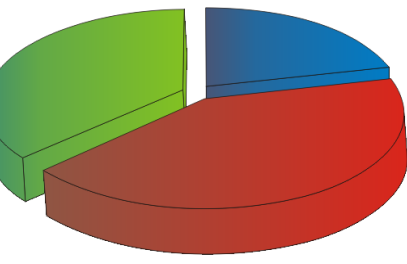

$c$

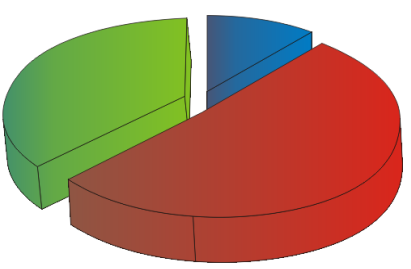

$d$

Fig. 3. Correlation of reservoir granulometric composition at shallow (a), medium $(b)$ and deep (c) depths, and also in depth range 1100-1200 $\mathrm{m}(d)$

Table 2

Alteration of petrophysical characteristics by depth in Pliocene age sediments

at Khamamdag-Deniz deposits

\begin{tabular}{|c|c|c|c|c|c|c|c|c|}
\hline \multirow{2}{*}{$\begin{array}{c}\text { Depth } \\
\text { range, } \mathrm{m}\end{array}$} & \multicolumn{3}{|c|}{ Granulometric composition, \% } & \multirow{2}{*}{ Carbonateness, \% } & \multirow{2}{*}{$\begin{array}{l}\text { Porosity, } \\
\quad \%\end{array}$} & \multirow{2}{*}{$\begin{array}{l}\text { Permeability, } \\
10^{-15} \mathrm{~m}^{2}\end{array}$} & $\begin{array}{l}\text { Density } \sigma \\
\mathrm{g} / \mathrm{cm}^{3}\end{array}$ & \multirow{2}{*}{$\begin{array}{c}\begin{array}{c}\text { Ultrasound } \\
\text { propagation } \\
\text { velocity } V, \mathrm{~m} / \mathrm{sec}\end{array} \\
V\end{array}$} \\
\hline & $\begin{array}{c}\text { Fractions over } \\
0,25-0,10\end{array}$ & $\begin{array}{l}\text { Fractions } \\
0,10-0,01 \\
\end{array}$ & \begin{tabular}{|c|} 
Fractions less \\
0,01 \\
\end{tabular} & & & & dry & \\
\hline & $\begin{array}{lll}0 & 20 & 40 \\
\end{array}$ & 204060 & 204060 & \begin{tabular}{l|ll}
0 & 20 & 40 \\
& &
\end{tabular} & $\begin{array}{l}5 \quad 1525 \\
\end{array}$ & Impermeability & 22.22 .4 & 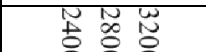 \\
\hline $502-834$ & T & & 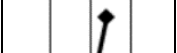 & $\uparrow$ & 8 & $0 \quad 60120$ & 4 & \\
\hline 835-1088 & 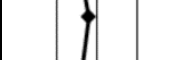 & & & \} & $p$ & 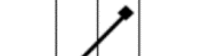 & P & \\
\hline 1100-1200 & & $I$ & & 1 & 11 & & & \\
\hline 1450-1800 & & & & & 1 & & & 8 \\
\hline 2500-3669 & & & & & & & & \\
\hline 3780-3835 & & & & & & & & \\
\hline 4025-4114 & & & & & 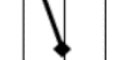 & D. & ] & \\
\hline 4114-4439 & & & & & & & & \\
\hline
\end{tabular}

At the same time relatively high permeability and porosity observed at depth 1100-1200 m (see fig. 3, d), where sandy-argillaceous aleurolites contain 46,5 $\%$ aleurite, $13,6 \%$ sands, $37,6 \%$ clays at carbonateness $17,0 \%$ and are characterized by low grading, may be explained by secondary porosity. This assumption is confirmed by relatively high density and velocity of ultrasound waves propagation (see table 1). Consequently, appearance of secondary rock porosity in conditions of Baku archipelago is rather realistic.

Visualization of depth alteration of petrophysical characteristics and correlation of granulometric composition of reservoirs was implemented by building corresponding graphical relations for Pliocene age sediments at Khamamdag-Deniz (table 2).

As it is seen from graphical presentations and table data, clean correlation and direct stable dependency between the studied petrophysical parameters is not observed. Obviously this is related to multiplicity of factors determining values of the studied parameters.

It should be noted that at depth $4114-4439 \mathrm{~m}$ oil and gas bearing rocks are discovered. This gives a reason to forecast presence of oil and gas reservoirs in deep strata of the deposit, moreover as above deviation from general regularity of deterioration of rocks porosity and permeability with depth was already explained. Similar phenomenon was also observed in previous studies [8,9], also proving possibility of preservation of primary productive properties of reservoir rocks, or newly obtained secondary productive properties, at relatively deep depths. This phenomenon is most typical for clays which in conditions of relatively high pressures and temperatures, by transforming into argillites, obtain 
secondary porosity and permeability related to it. This fact deserves special attention, as productive strata, not only within Khamamdag-Deniz area, but also within the whole Baku archipelago, are characterized by high clayliness and lays at deep depths with geothermy of $100{ }^{\circ} \mathrm{C}$ and more. This greatly assists to processes of clay reformation to argillites. Geodynamical and tectonic influences are expressed here in development of transverse compressive stresses, leading to appearance of fractures in brittle argillites, resembling very much fractures in argillites of Bazhenov formation (Upper Jurassic complex) in Western Siberia.

In our deposit (Khamamdag-Deniz) density of argillaceous sediments changes within $2,10-2,36 \mathrm{~g} / \mathrm{cm}^{2}$, porosity $-5,4-26,5 \%$, elultrasound waves propagation velocity - 1900-3500 m/sec. On the other part, alteration of reservoir properties in deep and shallow wells in different tectonic blocks shows that in each of them porosity and permeability, and also other petrophysical properties differ significantly. It indicates that during lithogenesis and metamorphism processes under influence of temperature and pressure sediments, having passed primary compaction stages, later may acquire secondary porosity [28-37].

\section{Influence of geodynamical regime on formation of geological structure}

It is evident, that making assumptions on secondary structural alterations of production reservoirs, it is necessary to touch upon geodynamical nature of deep tectonic conditions existed in territory of Baku archipelago. As it is known, in depths of Baku archipelago since time of opening Krasnogorsky rift existed complex geodynamical development regime, controlled by advance of Arabian plate in northern direction. In process of this advance north-eastern projection of Arabic plate was subjected to flexure strain by narrow north-western part of Iran-Afghan plate in north-eastern direction [10]. As result to end of Pliocene Southern Caspian basin was separated from Black sea with simultaneous formation of western flank of Baku archipelago. Due to the described processes at present earth crust within Baku archipelago continue to stay under influence of compressing stresses of northeastern orientation. At the same time, as known, bed of Southern Caspian sea is of complex graben structure, which aids to more intense lowering of sea bed, including Baku archipelago. On the other part, in the north, in zone of Apsheron-Pribalkhansky step, Southern Caspian bed moves below Middle Caspian bed, and on the southern flank - under narrow part of Iran-Afghan plate. All this together indicates presence in depths of Southern Caspian area, including territory of Baku archipelago, of compressing stresses of submeridional orientation. Nevertheless, more intense here stay stresses of north-eastern orientation, which is proved by northwestern - south-eastern orientation of anticlinal zones of Baku archipelago. From the above it comes that geodynamical regime within Baku archipelago is favorable enough to appearance of secondary porosity in rocks of sedimentary complex [38-46].

\section{Conclusions}

1. Lithofacial composition of rocks, tectonic and thermobaric conditions in sedimentary section of Baku archipelago at deep depths are favorable for formation of secondary porosity within sedimentary complex.

2. Generalization of granulometric data showed that compaction of poorly graded terrigenous sediments with depth negatively influences their primary reservoir properties (up to formation of secondary porosity in them).

3. Rocks reservoir properties have no direct connection to their carbonateness, but it positively influences on their secondary porosity and permeability formation.

4. Ultrasound waves velocity in reservoir rocks is directly proportional to density and reversely proportional in cases of development of secondary porosity.

5. In forecasting of deep strata productivity, together with usage of modern geophysical methods, it is appropriate to attract also petrophysical studies of core material.

\section{References}

1. Ali-Zade A.A., Akhmedov G.A., Akhmedov A.M., Aliev A.K., Zeinalov M.M. Geologiia neftianykh i gazovykh mestorozhdenii Azerbaidzhana [Geology of oil and gas fields of Azerbaijan]. Moscow, Nedra, $1966,390 \mathrm{p}$.
2. Iusifzade Kh.B. Primenenie sovremennykh tekhnologii $\mathrm{V}$ oblasti razvedki i dobychi neftegazovykh mestorozhdenii $\mathrm{v}$ azerbaidzhane [Application of modern technologies in the field of exploration and production of oil and gas fields in 
Azerbaijan]. Azerbaidzhanskoe neftianoe khoziaistvo, 2013, no.7-8, pp.3-13.

3. Akhmedov A.M. O geologicheskoi kharakteristiki i perspektivakh neftegazonosnosti ploshchadi Umid [On the geological characteristics and oil and gas potential of the Umid area]. Azerbaidzhanskoe neftianoe khoziaistvo, 2008, no.3, pp.19-22.

4. Babazade B.Kh., Putkaradze L.A. O poiskakh zalezhei gaza i nefti $\mathrm{v}$ pribrezhnoi morskoi zone Apsheronskogo poluostrova i Bakinskogo arkhipelaga [On the search for gas and oil deposits in the coastal sea zone of the Absheron Peninsula and the Baku Archipelago]. Geologiia nefti i gaza, 1961, no. 10, pp.7-11.

5. Rakhmanov R.R. Zakonomernosti formirovaniia i razmeshcheniia zon neftegazonakopleniia $\mathrm{V}$ mezozoiskikh otlozheniiakh Azerbaidzhana [Laws of formation and distribution of oil and gas accumulation zones in the Mesozoic sediments of Azerbaijan]. Baku, Elm, 1985, 108 p.

6. Rachinskii M.Z., Chilingar Dzh. Rezultaty geologo-razvedochnykh rabot 1990-2005 gg., geologicheskie aspekty perspektiv i kolichestvennaia otsenka [The results of geological exploration in 1990-2005, the geological aspects of the prospects and quantitative assessment]. Azerbaidzhanskoe neftianoe khoziaistvo, 2007, no.1, pp.7-15.

7. Volarovich M.P., Baiuk E.I., Efimova G.A. Uprugie svoistva mineralov pri vysokikh davleniiakh [Elastic properties of minerals at high pressures]. Moscow, Nauka, 1975, $130 \mathrm{p}$.

8. Babaev M.S., Sultanov L.A., Ganbarova Sh.A., Alieva T.A. O rezultatakh petrofizicheskikh issledovanii otlozhenii produktivnoi tolshchi neftegazonosnykh ploshchadei bakinskogo arkhipelaga [On the results of petrophysical studies of deposits of the productive stratum of oil and gas bearing areas of the Baku Archipelago]. Izvestiia vysshikh tekhnicheskikh uchebnykh zavedenii Azerbaidzhana, 2014, no.2, pp.7-12.

9. Gurbanov V.Sh., Sultanov L.A., Valiyev S.A., Babaeva M.T. The lithophysical and collector characteristics of mesozoic-cenozoic deposits of north-western part of the Caspian depression. Perm Journal of Petroleum and Mining Engineering, 2015, no. 17, pp.5-15. DOI: 10.15593/2224-9923/2015.17.1

10. Spravochnik po litologii [Handbook of lithology]. Ed. N.B. Vassoevich, V.L. Librovich, N.V. Logvinenko, V.I. Marchenko. Moscow, Nedra, 1983, 509 p.

11. Spravochnik po geologii nefti i gaza [Handbook of oil and gas geology]. Moscow, Nedra, $1988,480 \mathrm{p}$.
12. Hasanov A.B., Balakishibayli Sh.A. The influence of recent geodynamics on the physicomechanical state of the geological environment of the sedimentary cover. Materials of international workshop. Evaluation of synthetic elastic parameters of reservoirs, fluid phase saturation and temperatures in the depths. Baku, 2010, pp.101-108.

13. Kerimov K.M., Rakhmanov R.R., Kheirov M.B. Neftegazonosnost Iuzhno-Kaspiiskoi megavpadiny [Petroleum potential of the South Caspian megadepression]. Baku, 2001, $317 \mathrm{p}$.

14. Sokolov B.A. Evoliutsiia i neftegazonosnost osadochnykh basseinov [Evolution and petroleum potential of sedimentary basins]. Moscow, Nauka, 1980, $243 \mathrm{p}$.

15. Uspenskaia N.Iu., Tauson N.N. Neftegazonosnye provintsii i oblasti zarubezhnykh stran [Oil and gas provinces and regions of foreign countries]. Moscow, Nedra, 1972, 283 p.

16. Hasanov A.B., Melikov Kh.F. 3D model of productive layers according to data geophysics and petrophysics. Materials of international workshop. The influence of recent geodynamics on the physicmechanical state of the geological environment of the sedimentary cover. Baku, 2010, pp.101-108.

17. Aliyarov R.Y., Hasanov A.B., Aslanzade F.B., Samedzade A.A. Recognition of fluid flow zones in oil reservoirs by loq methods. Azerbayjan Geologist. Scientific Bulletin of the Azerbaijan Society of petroleum geologists, 2018, no.22, pp.121-128.

18. Ali-Zade A.A., Salaev S.G., Aliev A.I. Nauchnaia otsenka perspektiv neftegazonosnosti Azerbaidzhana i Iuzhnogo Kaspiia i napravlenie poiskovo-razvedochnykh rabot [Scientific assessment of the oil and gas potential of Azerbaijan and the South Caspian and the direction of exploration]. Baku, Elm, 1985, 227 p.

19. Landolt-Bornstein Tables. Physical properties of rocks. Ed. G. Argenheisen. N.Y., 1983, vol. V, 373 p.

20. Theoretical and experimental investigations of physical properties of rocks and minerals under extreme p,T-conditions. Berlin, Academie Verlag, 1979, 232 p.

21. Afandiyeva M.A., Guliyev I.S. Maikop Group - shale hydrocarbon complex in Azerbaijan. 75th EAGE Conference \& Exhibition. London, 2013. DOI: 10.3997/2214-4609.20130979

22. Salmanov A.M., Suleimanov A.M., Magerramov B.I. Paleogeologiia neftegazonosnykh raionov Azerbaidzhana [Paleogeology of oil and gas regions of Azerbaijan]. Baku, 2015, 470 p.

23. Kerimov K.M. Glubinnoe stroenie i neftegazonosnost depressionnykh zon Azerbaidzhana i Iuzhnogo 
Kaspiia [Depth structure and oil and gas potential of depressed zones of Azerbaijan and the South Caspian]. Baku, 2009, 438 p.

24. Fizicheskie svoistva gornykh porod i poleznykh iskopaemykh [Physical properties of rocks and minerals]. Ed. N.B. Dortman. Moscow, Nedra, 1976, 527 p.

25. Kozhevnikov D.A. Petrofizicheskaia invariantnost granuliarnykh kollektorov [Petrophysical invariance of granular reservoirs]. Geofizika, 2001, no.4, pp.31-37.

26. Babaev M.S. Kollektorskie parametry porod vybrosov griazevykh vulkanov Bakinskogo arkhipelaga (na primere o.Duvanny i o.Bulla) [Collector parameters of rocks of emissions of mud volcanoes of the Baku Archipelago (on example of Is. Duvanna and Is. Bulla)]. Tematicheskii sbornik nauchnykh trudov. Baku, 1991, pp.82-84.

27. Sostavlenie kataloga kollektorskikh svoistv mezokainozoiskikh otlozhenii mestorozhdenii neftigaza i perspektivnykh struktur Azerbaidzhana [Compilation of a catalog of reservoir properties of the Meso-Cenozoic deposits of oil-gas fields and prospective structures of Azerbaijan]. Otchet Nauchnoissledovatelskogo instituta geofiziki - 105-2009. Fondy Upravleniia geofiziki i geologii. Baku, 2010.

28. Gurbanov V.Sh., Narimanov N.R., Sultanov L.A., Babaev M.S. Geologicheskoe stroenie i kollektorskie svoistva mezokainozoiskikh otlozhenii DzharlySaatlinskogo neftegazonosnogo raiona na bolshikh glubinakh [Geological structure and reservoir properties of meso-cenozoic deposits of Dzharly-Saatli oil and gas region at great depths]. Izvestiia Uralskogo gosudarstvennogo gornogo universiteta, 2016, no.2(42), pp.25-27. DOI 10.21440/2307-2091-2016-2-25-27

29. Gurbanov V.Sh., Sultanov L.A. On oil-andgas content of Mesozoic deposits in Azerbaijan [On oil-and-gas content of Mesozoic deposits in Azerbaijan]. Perm Journal of Petroleum and Mining Engineering, 2015, no.16, pp.7-13. DOI: 10.15593/2224-9923/2015.16.1

30. Babaev M.S., Sultanov L.A., Ganbarova Sh.A., Alieva T.A. O rezultatakh petrofizicheskikh issledovanii otlozhenii produktivnoi tolshchi neftegazonosnykh ploshchadei Bakinskogo arkhipelaga [On the results of petrophysical studies of deposits of the productive stratum of oil and gas bearing areas of the Baku Archipelago]. Izvestiia vysshikh tekhnicheskikh uchebnykh zavedenii Azerbaidzhana, 2014, no.2, pp.7-12.

31. Gurbanov V.Sh., Sultanov L.A., Abbasova G.G. Litologo-petrograficheskie i kollektorskie svoistva mezokainozoiskikh otlozhenii Prikaspiisko-Gubinskogo neftegazonosnogo raiona [Litho-petrographic and reservoir properties of the Meso-Cenozoic sediments of the Caspian-Guba oil and gas region]. Geofizicheskie novosti Azerbaidzhana, 2014, no.3-4, pp.10-13.

32. Sultanov L.A., Nadzhaf-Kuieva V.M., Abbasova G.G. O zakonomernosti raspredeleniia skorosti prodolnykh voln i plotnosti osadochnykh porod Prikaspiisko-kubinskoi oblasti i mezhdurechia Kury i Gabyrry [On the regularity of the distribution of the velocity of longitudinal waves and the density of sedimentary rocks of the Caspian-Cuban region and the interfluve of the Kura and Gabyrry]. XX Gubkinskie chteniia. Tezisy dokladov. Moscow, 2013.

33. Gurbanov V.Sh., Babaev M.S., Sultanov L.A., Rustamova R.E. Kratkaia geologo-geofizicheskaia kharakteristika razreza zemnoi kory raiona Saatlinskoi sverkhglubokoi skvazhiny SG-1 [Brief geological and geophysical characteristics of the crustal section of the Saatly superdeep well SG-1]. Azerbaidzhan geologu, 2012, no.16, p.31-37.

34. Physical properties of the mineral system of the Earth s interior. International monograph Project 3 CAPG. Praha, 1985, $564 \mathrm{p}$

35. Lebedev T.S. Model studies of physical properties of mineral matter in high pressure - temperature experiments. Phys. Earth and Planet. Inter., 1980, vol.25, pp.292-303. DOI: 10.1016/0031-9201(80)90126-0

36. Mekhtiev U.Sh., Kheirov M.B. Litologopetrograficheskie osobennosti i kollektorskie svoistva porod kalinskoi i podkirmakinskoi svit Apsheronskoi neftegazonosnoi oblasti Azerbaidzhana [Lithopetrographic features and reservoir properties of rocks of the Kalin and Podkirmak suite of the Absheron oil and gas region of Azerbaijan]. Baku, $2007,238 \mathrm{p}$.

37. Gurbanov B.Sh., Sultanov L.A. et al. Geologicheskom stroenii i rezultatakh petrofizicheskikh issledovaniia otlozhenii produktivnoi tolshchi neftianogo mestorozhdeniia Garasu Bakinskogo arkhipelaga $\mathrm{V}$ usloviiakh sushchestvuiushchego geodinamicheskogo rezhima [Geological structure and the petrophysical properties of rocks of Productive unit of Qarasu deposit of Baku archipelago under conditions exiting geodynamic regime]. Respublika Kazakhstan gorno-geologicheskii zhurnal, 2018, no. 2(54), pp.17-23.

38. Gasanov A.B., Sultanov L.A. Geologopetrofizicheskie osobennosti kollektorov mestorozhdenii Bakinskogo arkhipelaga [Geological and petrophysical features of reservoirs in the Baku archipelago]. Izvestiia 
vysshikh tekhnicheskikh uchebnykh zavedenii Azerbaidzhana, 2018, no.3, pp.7-16.

39. Sultanov L.A. Geologicheskoe stroenie, analiz zakonomernykh izmenenii fizicheskikh svoistv porod $\mathrm{i}$ prognozirovaniia glubokozalegaiushchikh neftegazovykh kollekterov mezokainozoiskikh otlozhenii Azerbaidzhana [Geological structure, analysis of regular changes in the physical properties of rocks and forecasting of deeplying oil and gas reservoirs of the Meso-Cenozoic sediments of Azerbaijan]. Bakirovskie chteniia. Sbornik nauchnykh trudov. Moscow, Neft i gaz, 2018, pp.156-160.

40. Gurbanov V.Sh., Hasanov A.B., Sultanov L.A. Physical characteristics and filtration capacitance properties (FCP) of prospective oil and gas bearing horizons in the lower levels of Productive thickness (PT) in the land area of Azerbaijan. Modern problems of innovative technologies in oil and gas production and applied mathematics. International conference dedicated to the 90th anniversary of academician AZAD MIRZAJANZADE. Baku, 2018, pp.418-419.

41. Sultanov L.A. Geologicheskie i kollektorskie svoistva otlozhenii produktivnoi tolshchi ploshchadi Kalamaddin v predelakh Prikurinskoi neftegazonosnoi mezhgornoi vpadiny [Geological and reservoir properties of deposits of the productive stratum of the Kalamaddin area within the limits of the Prikurinsk oil and gas intermountain basin]. Respublika Kazakhstan gornogeologicheskom zhurnal, 2018, no.3(55), pp.25-31.
42. Sultanov L.A. The collector characteristics of mesozoic-cenozoic deposits of North-West Part Of South Caspian Basin. Modern problems of innovative technologies in oil and gas production and applied mathematics. International conference dedicated to the 90th anniversary of academician AZAD MIRZAJANZADE. Baku, 2018, pp.561-563.

43. Khain V.E. Tektonika neftegazonosnykh oblastei Iugo-Vostochnoe pogruzhenie Bolshogo Kavkaza [Tectonics of oil and gas regions SouthEastern immersion of the Greater Caucasus]. Moscow, Gostoptekhizdat, 1958, 224 p.

44. Narimanov N.R. Geodinamicheskie aspekty formirovaniia osadochnogo chekhla Iuzhno-Kaspiiskoi vpadiny [Geodynamic aspects of the sedimentary cover formation of South-Caspian depression]. Geologiia nefti i gaza, 2003, no.6, pp.26-31.

45. Sultanov L.A., Narimanov N.R., Samed-Zade A.A. Geologicheskoe stroenie mestorozhdeniia Neft Dashchlary i analiz zakonomernosti izmeneniia kollektorskikh svoistv porod produktivnoi tolshchi $\mathrm{v}$ zavisimosti ot glubi [Geological structure of the Neft Dachlary deposit and analysis of the pattern of changes in reservoir properties of the productive rocks depending on the depth of their occurrence]. Bulatovskie chteniia. II Mezhdunarodnaia nauchno-prakticheskaia konferentsiia. Krasnodar, Kubanskii gosudarstvennyi tekhnologicheskii universitet, 2018, vol. 1, pp.196-203.

\section{Библиографический список}

1. Геология нефтяных и газовых месторождений Азербайджана / А.А. Али-заде, Г.А. Ахмедов, А.М. Ахмедов, А.К. Алиев, М.М. Зейналов. Недра, 1966. - 390 с.

2. Юсифзаде Х.Б. Применение современных технологий в области разведки и добычи нефтегазовых месторождений в Азербайджане // Азербайджанское нефтяное хозяйство. - 2013. № 7-8. - С. 3-13.

3. Ахмедов А.М. О геологической характеристике и перспективах нефтегазоносности площади Умид // Азербайджанское нефтяное хозяйство. - 2008. - № 3. - С. 19-22.

4. Бабазаде Б.Х., Путкарадзе Л.А. О поисках залежей газа и нефти в прибрежной морской зоне Апшеронского полуострова и Бакинского архипелага // Геология нефти и газа. - 1961. - № 10. - С. 7-11.

5. Рахманов P.P. Закономерности формирования и размещения зон нефтегазо-накопления в мезозойских отложениях Азербайджана. - Баку: Элм, 1985. - 108 с.
6. Рачинский М.3., Чилингар Дж. Результаты геологоразведочных работ 1990-2005 гг., геологические аспекты перспектив и количественная оценка // Азербайджанское нефтяное хозяйство. 2007. - № 1. - C. 7-15.

7. Воларович М.П., Баюк Е.И., Еэфимова Г.А. Упругие свойства минералов при высоких давлениях. - Москва: Наука, 1975. - С. 130.

8. О результатах петрофизических исследований отложений продуктивной толщи нефтегазоносных площадей Бакинского архипелага / М.С. Бабаев, Л.А. Султанов, Ш.А. Ганбарова, Т.А. Алиева // Известия высших технических учебных заведений Азербайджана. - 2014. - № 2. C. 7-12.

9. Литолого-петрографические и коллекторские характеристики мезокайнозойских отложений северо-западной части Южно-Каспийской впадины / В.Ш. Гурбанов, Л.А. Султанов, С.А. Валиев, М.Т. Бабаева // Вестник Пермского национального исследовательского политехнического университета. 
Геология. Нефтегазовое и горное дело. - 2015. № 17. - C. 5-15. DOI: 10.15593/2224-9923/2015.17.1

10. Справочник по литологии / под ред. Н.Б. Вассоевича, В.Л. Либровича, Н.В. Логвиненко, В.И. Марченко. - Москва: Недра, 1983. - 509 с.

11. Справочник по геологии нефти и газа. Москва: Недра, 1988. - 480 с.

12. Hasanov A.B., Balakishibayli Sh.A. The influence of recent geodynamics on the physicomechanical state of the geological environment of the sedimentary cover. Materials of international workshop // Evaluation of synthetic elastic parameters of reservoirs, fluid phase saturation and temperatures in the depths. - Baku, 2010. - P. 101-108.

13. Керимов К.М., Рахманов Р.Р., Хеиров М.Б. Нефтегазоносность Южно-Каспийской мегавпадины. - Баку. 2001. - 317 с.

14. Соколов Б.А. Эволюция и нефтегазоносность осадочных бассейнов. - Москва: Наука, 1980. $-243 \mathrm{c}$.

15. Успенская Н.Ю., Таусон Н.Н. Нефтегазоносные провинции и области зарубежных стран. - Москва: Недра, 1972. - 283 с.

16. Hasanov A.B., Melikov Kh.F. 3D model of productive layers according to data geophysics and petrophysics. Materials of international workshop // The influence of recent geodynamics on the physicmechanical state of the geological environment of the sedimentary cover. - Baku, 2010. - P. 101-108.

17. Recognition of fluid flow zones in oil reservoirs by loq methods / R.Y. Aliyarov, A.B. Hasanov, F.B. Aslanzade, A.A. Samedzade // Azerbayjan Geologist Scientific Bulletin of the Azerbaijan Society of petroleum geologists. - 2018. - № 22. - P. 121-128.

18. Али-Заде А.А., Салаев С.Г., Алиев А.И. Научная оценка перспектив нефтегазоносности Азербайджана и Южного Каспия и направление поисково-разведочных работ. - Баку: Элм, 1985. - 227c.

19. Landolt-Bornstein tables. Physical properties of rocks / Ed. G. Argenheisen. - N.Y., 1983. - Vol. V. -373 p.

20. Theoretical and experimental investigations of physical properties of rocks and minerals under extreme p,T-conditions. - Berlin: Academie Verlag, 1979. - $232 \mathrm{p}$.

21. Afandiyeva M.A., Guliyev I.S. Maikop Group shale hydrocarbon complex in Azerbaijan // 75th EAGE Conference \& Exhibition. - London, 2013. DOI: 10.3997/2214-4609.20130979

22. Салманов А.М., Сулейманов А.М, Магеррамов Б.И. Палеогеология нефтегазоносных районов Азербайджана. - Баку, 2015. - 470 с.
23. Керимов К.М. Глубинное строение и нефтегазоносность депрессионных зон Азербайджана и Южного Каспия. - Баку, 2009. - 438 с.

24. Физические свойства горных пород и полезных ископаемых / под ред. Н.Б. Дортман. Москва: Недра, 1976. - 527 с.

25. Кожевников Д.А. Петрофизическая инвариантность гранулярных коллекторов // Геофизика. - 2001. - № 4. - С. 31-37.

26. Бабаев М.С. Коллекторские параметры пород выбросов грязевых вулканов Бакинского архипелага (на примере о. Дуванны и о. Булла) // Тематический сборник научных трудов. - Баку: Издательство Азербайджанского ИУ, 1991. C. $82-84$.

27. Составление каталога коллекторских свойств мезокайнозойских отложений месторождений нефти-газа и перспективных структур Азербайджана: отчет Научно-исследовательского института геофизики - 105-2009 / Фонды Управления геофизики и геологии. - Баку, 2010.

28. Геологическое строение и коллекторские свойства мезокайнозойских отложений Джарлы-Саатлинского нефтегазоносного района на больших глубинах / В.Ш. Гурбанов, Н.Р. Нариманов, Л.А. Султанов, М.С. Бабаев // Известия Уральского государственного горного университета. - 2016. - № 2 (42). - С. 25-27. DOI 10.21440/2307-2091-2016-2-25-27

29. Гурбанов В.Ш., Султанов Л.А. О нефтегазоносности мезозойских отложений Азербайджана // Вестник Пермского национального исследовательского политехнического университета. Геология. Нефтегазовое и горное дело. - 2015. - № 16. - С. 7-13. DOI: 10.15593/2224-9923/2015.16.1

30. О результатах петрофизических исследований отложений продуктивной толщи нефтегазоносных площадей Бакинского архипелага / М.С. Бабаев, Л.А. Султанов, Ш.А. Ганбарова, Т.А. Алиева // Известия высших технических учебных заведений Азербайджана. - 2014. - № 2. C. 7-12.

31. Гурбанов В.Ш., Султанов Л.А., Аббасова Г.Г. Литолого-петрографические и коллекторские свойства мезокайнозойских отложений Прикаспийско-Губинского нефтегазоносного района // Геофизические новости Азербайджана. - 2014. № 3-4. - С. 10-13.

32. Султанов Л.А., Наджаф-Куиева В.М., Аббасова Г.Г. О закономерности распределения скорости продольных волн и плотности 
осадочных пород Прикаспийско-Кубинской области и междуречья Куры и Габырры // ХХ Губкинские чтения: тезисы докладов. Москва, 2013.

33. Краткая геолого-геофизическая характеристика разреза земной коры района Саатлинской сверхглубокой скважины СГ-1 / В.Ш. Гурбанов, М.С. Бабаев, Л.А. Султанов, Р.Э. Рустамова // Азербайджан геологу. - 2012. - № 16 . C. 31-37.

34. Physical properties of the mineral system of the Earth's interior // International monograph Project 3 CAPG. - Praha, 1985. - 564 p

35. Lebedev T.S. Model studies of physical properties of mineral matter in high pressure temperature experiments // Phys. Earth and Planet. Inter. - 1980. - Vol. 25. - P. 292-303. DOI: 10.1016/0031-9201(80)90126-0

36. Мехтиев У.Ш., Хеиров М.Б. Литологопетрографические особенности и коллекторс-кие свойства пород калинской и подкирмакинс-кой свит Апшеронской нефтегазоносной области Азербайджана. - Баку, 2007. - 238 с.

37. Геологическое строение и результаты петрофизических исследований отложений продуктивной толщи нефтяного месторождения Гарасу Бакинского архипелага в условиях существующего геодинамического режима / В.Ш. Гурбанов, Л.А. Султанов [и др.] // Республика Казахстан - горно-геологический журнал. - 2018. - № 2 (54). - С. 17-23.

38. Гасанов А.Б., Султанов Л.А. Геологопетрофизические особенности коллекторов месторождений Бакинского архипелага // Известия высших технических учебных заведений Азербайджана. - 2018. - № 3. - С. 7-16.

39. Султанов Л.А. Геологическое строение, анализ закономерных изменений физических свойств пород и прогнозирования глубокозалегающих нефтегазовых коллекторов мезокайнозойских отложений Азербайджана //
Бакировские чтения: сборник научных трудов. Москва: Нефть и газ, 2018. - С. 156-160.

40. Gurbanov V.Sh., Hasanov A.B., Sultanov L.A. Physical characteristics and filtration capacitance properties (FCP) of prospective oil and gas bearing horizons in the lower levels of Productive thickness (PT) in the land area of Azerbaijan // Modern problems of innovative technologies in oil and gas production and applied mathematics: International conference dedicated to the 90th anniversary of academician AZAD MIRZAJANZADE. - Baku, 2018. - C. 418-419.

41. Султанов Л.А. Геологические и коллекторские свойства отложений продуктивной толщи площади Каламаддин в пределах Прикуринской нефтегазоносной межгорной впадины // Республика

Казахстан - горно-геологический журнал. - 2018. № 3 (55). - С. 25-31.

42. Sultanov L.A. The collector characteristics of mesozoic-cenozoic deposits of North-West part of South Caspian Basin // Modern problems of innovative technologies in oil and gas production and applied mathematics: International conference dedicated to the 90th anniversary of academician AZAD MIRZAJANZADE. - Baku, 2018. C. 561-563.

43. Хаин В.Е. Тектоника нефтегазоносных областей юго-восточного погружения Большого Кавказа. - Москва: Гостоптехиздат, 1958. - 224 с.

44. Нариманов Н.Р. Геодинамические аспекты формирования осадочного чехла ЮжноКаспийской впадины // Геология нефти и газа. 2003. - № 6. - С. 26-31.

45. Султанов Л.А., Нариманов Н.Р., Самед-заде А.А. Геологическое строение месторождения Нефт Дашлары и анализ закономерности изменения коллекторских свойств пород продуктивной толщи в зависимости от глубины их залегания // Булатовские чтения: II Международная научнопрактическая конференция / Кубанский государственный технологический университет. Краснодар, 2018. - Т. 1. - С. 196-203.

Please cite this article in English as:

Gurbanov V.Sh., Hasanov A.B, Sultanov L.A., Babaev M.S. Infuence of geodynamical regime on formation of geological structure and petrophysical characteristics of pliocene sediments in Khamamdag-Deniz field in Baku archipelago. Perm Journal of Petroleum and Mining Engineering, 2019, vol.19, no.2, pp.128-137. DOI: 10.15593/2224-9923/2019.2.3

Просьба ссылаться на эту статью в русскоязычных источниках следующим образом:

Влияние геодинамического режима на формирование геологического строения и петрофизические характеристики плиоценовых отложений месторождения Хамамдаг-Дениз Бакинского архипелага / В.Ш. Гурбанов, А.Б. Гасанов, Л.А. Султанов, М.С. Бабаев // Вестник Пермского национального исследовательского политехнического университета. Геология. Нефтегазовое и горное дело. - 2019. - Т.19, №2. - C.128-137. DOI: 10.15593/2224-9923/2019.2.3 